\title{
Composite Laser Claddings for Corrosion Protection of Outer Surfaces of Storage Containers for Spent Nuclear Fuel in Underground Repositories
}

\author{
Pavla Bartoň Klufová ${ }^{1}$, Antonín Kř́žž ${ }^{1}$, Duliškovič Josef ${ }^{1}$, Marek Vostřák ${ }^{2}$ \\ ${ }^{1}$ Faculty of Mechanical Engineering, University of West Bohemia. Univerzitní 2732/8, 30614 Pilsen. Czech Re- \\ public.E-mail: klufovap@fst.zcu.cz,kriz@kmm.zcu.cz, zozemir@students.zcu.cz \\ ${ }^{2}$ New Technologies - Research Center, University of West Bohemia. Univerzitní 2732/8, 30614 Pilsen. Czech \\ Republic. E-mail: mvostrak@ntc.zcu.cz
}

The present contribution examines the structures of and corrosion processes in copper-basalt composite laser claddings on a steel substrate. The cladding material was a laboratory-prepared mixture of the following components: Oerlikon METCO $55(\mathrm{Cu}>99.9 \%)$ and basalt powder. The metallographic structures of copper-basalt composite laser claddings were studied using optical and scanning electron microscopy. The adhesion of the claddings to the substrate was testing using the non-standardized Mercedes test. A potentiodynamic corrosion test in artificial mine water was performed on a specimen of the composite laser cladding. The test results were compared against those for a reference high-purity copper alloy C10100 and AISI 304 steel. The findings were interpreted in terms of the potential of copper-basalt composite laser claddings to be used as corrosion protection coatings on steel components in nuclear power applications.

Keywords: laser cladding, copper, basalt, composite, storage containers, nuclear fuel

\section{Introduction}

Underground repositories for permanent storage of containers with high-level radioactive waste and spent nuclear fuel are planned to be built in the Czech Republic and their operation is to commence in 2065 [1].

The first surveys conducted to find a suitable site with geologically stable bedrock in a sufficient distance from potential active faults date back to the 1990s. With the planned day of construction of a Czech underground repository approaching, both general public and research teams from various disciplines begin to take greater interest in disposal of high-level radioactive waste and spent nuclear fuel. The researchers have been working continuously on finding optimal solutions to seemingly basic problems which involve the concept of an underground repository and engineering design of storage containers [2].

The underground repository concept preferred by the Czech Radioactive Waste Repository Authority (RAWRA) is based on disposal of storage containers (with high-level radioactive waste or spent nuclear fuel) in a deep borehole in geologically stable crystalline rock. The bottom of the deep borehole would be approximately 500 metres below the surface. After disposal of storage containers, the borehole would be filled with bentonite [1]. The surface of the storage containers would therefore be exposed to corrosive and degradation effects. These must be minimized.

The Czech Republic maintains collaboration with many European countries which plan to build underground repositories for storage containers with highlevel radioactive waste or spent nuclear fuel. A wellknown solution is a Swedish storage container which comprises a two-layer jacket of copper ( $50 \mathrm{~mm}$ in thickness) and stainless steel [1].

Although the use of high-purity copper for corrosion protection of a storage container is justifiable, it is hardly a once-and-for-all solution. The global deposits of copper are limited. With the amount of spent nuclear fuel and high-level radioactive waste on the rise across the globe, it does not appear reasonable to bury this precious metal in underground repositories. Copper and its alloys are indispensable materials to a number of sectors (food industry, electrical engineering and others) [1] [2].

The experiments describe below were designed for finding an alternative solution for corrosion protection of storage containers.

\section{Laser Cladding Technology}

Laser cladding relies on the high-energy-density laser beam to melt the base material along with the cladding material. The latter may be in the form of powder or wire. The cladding process produces a narrow region, in which the melted cladding material and base material become metallurgically bonded. Their solidification thus leads to strong metallurgical bonds which provide the deposit with good cohesion as well as adhesion to the base material. The goal of laser cladding 
is to create a weld cladding with desired properties and chemical composition on the base material without extensive dilution $(>10 \%)$ between the two metals [3].

Laser clad deposits possess specific properties (resistance to corrosion, cavitation, erosion, thermal exposure and abrasive and adhesive wear, and other characteristics). The products typically selected for cladding comprise machine parts, such as turbine blades, valve seats, shafts, hydraulic pump components, hot forming dies, injection moulds for plastics, drilling tools, and metal 3D models (in rapid prototyping) [3].

\section{Experiments}

The purpose of the experiments was to find an alternative solution for corrosion protection of storage containers for high-level radioactive waste and spent nuclear fuel in underground repositories. As part of this effort, development of a new composite material was undertaken.

Tab. 1 Metco 55 powder; specifications and properties declared by the manufacturer [5]

\begin{tabular}{cccccc}
\hline & Copper content & Powder particle size & Morphology & Melting point & Density \\
\hline $\begin{array}{c}\text { METCO } \\
\mathbf{5 5}\end{array}$ & $\mathrm{Cu}$ min. $>99 \%$ & $45-90 \mu \mathrm{m}$ & Spherical & $1083{ }^{\circ} \mathrm{C}$ & $3-4 \mathrm{~g} / \mathrm{cm}^{3}$ \\
\hline
\end{tabular}

Prior to the experiments, the basalt powder was examined using X-ray diffraction to identify its phase composition. The phases and their melting temperatures are listed in Tab. 2. The entire diffraction pattern of the basalt powder is shown in Graph 1.

The substrate for laser cladding was scotch-brite brushed plate of C45 steel. Its thickness was $20 \mathrm{~mm}$ and the flat side dimensions were $140 \times 140 \mathrm{~mm}$. The chemical composition of the $\mathrm{C} 45$ steel substrate is given in Tab. 3.
Composite material consists of at least two components or phases which are combined in a specific way to reach unique mechanical, physical and chemical properties. There are two main types of components: matrix and

the reinforcing phase [4] aggressive environment of an underground repository was intended to match the corrosion protection performance of the Swedish solution while reducing the amount of copper used for the outer surface of the container.

A C45-steel substrate was laser clad using a composite powder material having a matrix of high-purity copper (Oerlicon METCO 55 filler powder) and a filler comprising basalt powder provided by EUTIT, s.r.o. The copper-basalt composite powder consisted of 85 wt. \% copper (METCO 55) and 15 wt. \% basalt. Oerlikon METCO 55 specifications are given in Tab.

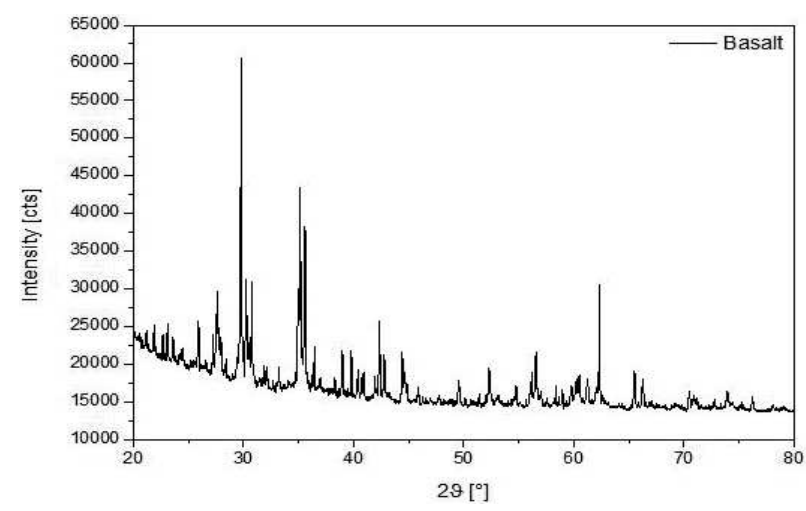

Graph 1 The full diffraction pattern of the basalt powder
The corrosion resistance of the material in the non-

Tab. 2 Phase composition of the basalt powder found by X-ray diffraction

\begin{tabular}{cccccccc}
\hline No. & $\begin{array}{c}\text { Compound } \\
\text { name }\end{array}$ & $\begin{array}{c}\text { Chemical } \\
\text { formula }\end{array}$ & $\begin{array}{c}\text { Melting } \\
\text { temperature }\left[{ }^{\circ} \mathbf{C}\right]\end{array}$ & $\mathbf{N o}$ & $\begin{array}{c}\text { Compound } \\
\text { name }\end{array}$ & $\begin{array}{c}\text { Chemical } \\
\text { formula }\end{array}$ & $\begin{array}{c}\text { Melting } \\
\text { temperature }\left[{ }^{\circ} \mathbf{C}\right]\end{array}$ \\
\hline $\mathbf{1}$ & Periclase & $\mathrm{MgO}$ & $2852[6]$ & $\mathbf{6}$ & Pyroxene & $\mathrm{MgSiO}_{3}$ & $1590[9]$ \\
\hline $\mathbf{2}$ & Quartz & $\mathrm{SiO}_{2}$ & $1470[7]$ & $\mathbf{7}$ & Sillimanite & $\mathrm{Al}_{2} \mathrm{SiO}_{5}$ & $1850[10]$ \\
\hline $\mathbf{3}$ & Titanite & $\mathrm{CaTiSiO}_{5}$ & $1382[7]$ & $\mathbf{8}$ & Enstatite & $\mathrm{MgSiO}_{3}$ & $1557[11]$ \\
\hline $\mathbf{4}$ & Cristobalite & $\mathrm{SiO}_{2}$ & $1713[7]$ & $\mathbf{9}$ & Mullite & $\mathrm{Al}_{6} \mathrm{SiO}_{13}$ & $1830[12]$ \\
\hline $\mathbf{5}$ & $\begin{array}{c}\text { Calcium } \\
\text { Aluminium } \\
\text { Oxide }\end{array}$ & $\mathrm{Al}_{2} \mathrm{CaO}_{4}$ & $1600[8]$ & $\mathbf{1 0}$ & Forsterite & $\mathrm{Mg}_{2} \mathrm{SiO}_{4}$ & $1890[7]$ \\
\hline
\end{tabular}

Tab. 3 Chemical composition of C45 steel, element content in weight per cent [13]

\begin{tabular}{lllllll}
\hline & $\mathbf{C}$ & Si & Mn & Cr & P & S \\
\hline C45 substrate & $0.42-0.50$ & $<0.40$ & $0.50-0.80$ & $<0.40$ & $<0.045$ & $<0.045$ \\
\hline
\end{tabular}

Fig. 1 is a schematic illustration of the laser cladding process where the cladding direction and order of laser tracks are shown. Fig. 1 shows a total of 5 regions identified as ZONE 1 through ZONE 5 which 
indicate the following: ZONE 1 (start of laser cladding process on the specimen); ZONE 2 (ends of the first tracks); ZONE 3 (central region of the laser clad); ZONE 4 (start of the last cladding track); ZONE 5 (end of the laser track). The thickness of the composite laser cladding was increased by depositing three layers on top of each other (layer A - the first layer which was diluted by mixing with the $\mathrm{C} 45$ substrate; layer $\mathrm{B}$ - interlayer; layer $\mathrm{C}$ - the surface of the laser cladding).

Fig. 2 is a macrograph of the copper-basalt composite laser cladding.

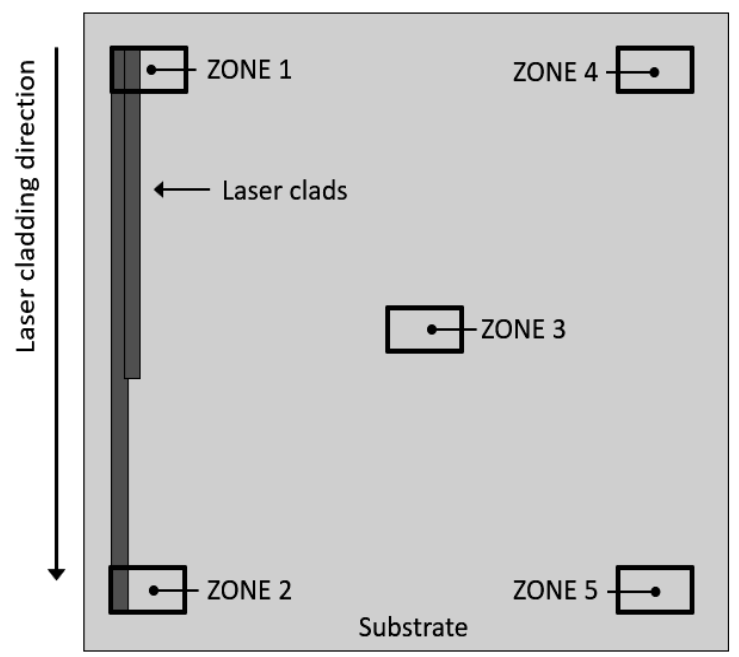

Fig. 1 Schematic representation of the laser cladding process; ZONE 1, 2, 3, 4, 5 are five different regions in the laser clad

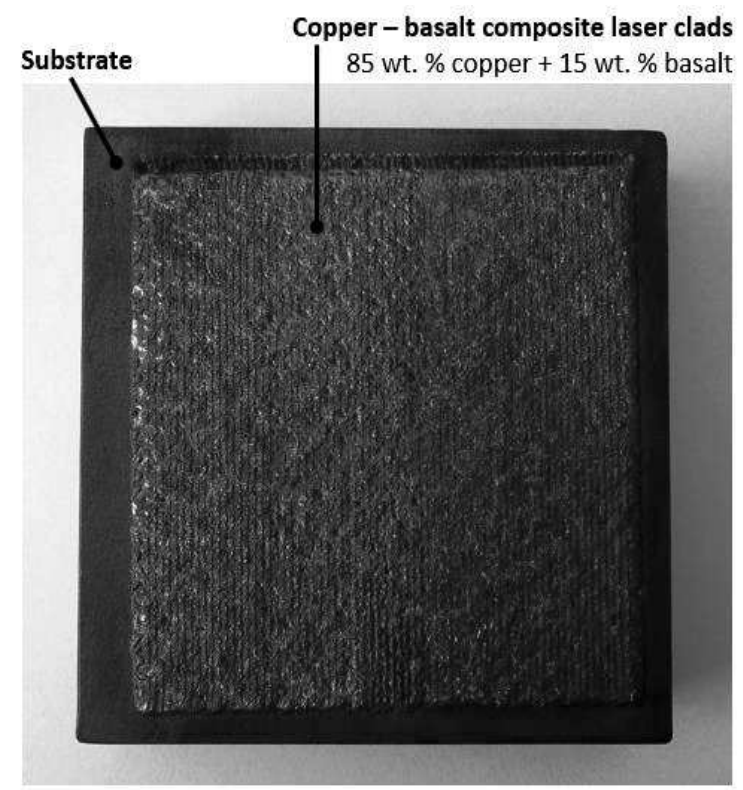

Fig. 2 A macrograph of the copper-basalt composite laser cladding

Solid-state disc laser Trumpf TruDisk 8002 was used. Its wavelength was $\lambda=1030 \mathrm{~nm}$ and the spot size was $=3.4 \mathrm{~mm}$. The laser cladding powder mixture was supplied via powder feeder GTV PF 2/2 MH to coaxial-feeding cladding head Precitec YC52 with a four-beam nozzle. The assist and shielding gas was 5.0-purity argon [3]. The overlap between the laser tracks was $30 \%$ of a single track width.

\section{Metallographic Examination}

The laser clads were examined using metallographic techniques, Carl Zeiss Z1M light microscope with Axiovision software, and an SE (JEOL JSM 6490 LV) microscope with an EDS analyser (Oxford Instruments INCA 300). Their microstructures were revealed using a chemical mixture available under the name Robin. The interface between the laser clad and the base material was etched with $3 \%$ Nital [14] [15].

Fig. 3 shows the surface of the composite copperbasalt laser cladding (layer C). A high-purity copper layer $15-20 \mu \mathrm{m}$ in thickness is clear to be seen on the laser cladding surface. The sub-surface layer consists of dendrites with distinct interdendritic spaces containing copper. Fig. 4 shows the interface between the laser cladding (layer A) and the substrate. The laser cladding structure comprises planar and columnar dendrites.

Fig. 5 shows a crack at the fusion boundary between the laser cladding and the substrate in ZONE 2. This crack initiated during deposition of layer $B$ and continued to spread across layer A into the C45 steel substrate. Cracks in the copper-basalt composite laser cladding substantially impair its corrosion resistance (as described in the section Potentiodynamic Corrosion Test). Fig. 6 shows the fusion boundary between the laser cladding and the substrate in ZONE 5 (where the laser cladding process ended). The microstructure was revealed by etching with a mixture of Robin and Nital 3\%. The micrograph clearly shows the presence of iron and its alloys in layer A of the composite copper-basalt laser cladding. Dilution between the laser cladding and the substrate is undesirable but it cannot be avoided completely in the laser cladding process.

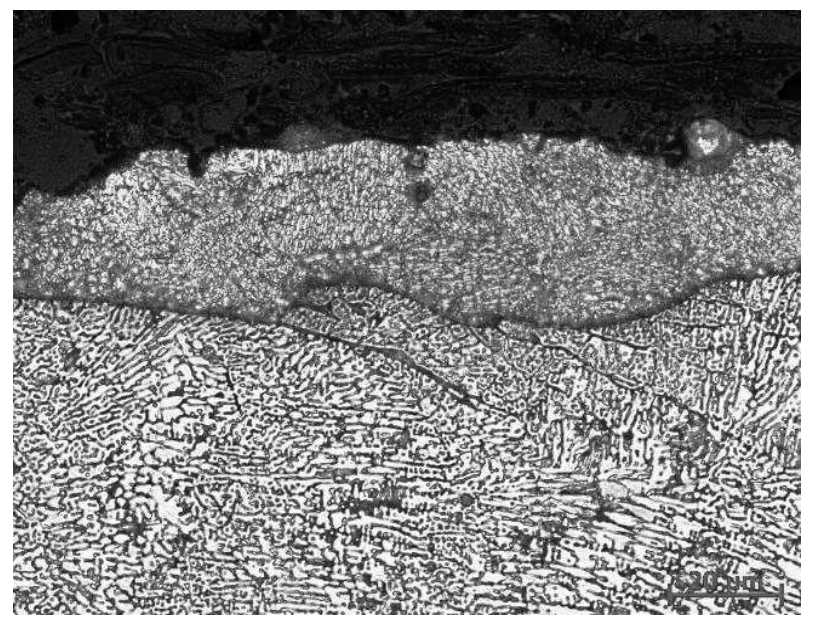

Fig. 3 ZONE 1; laser cladding surface - layer C; Robin etchant; magnification $500 \times$ 


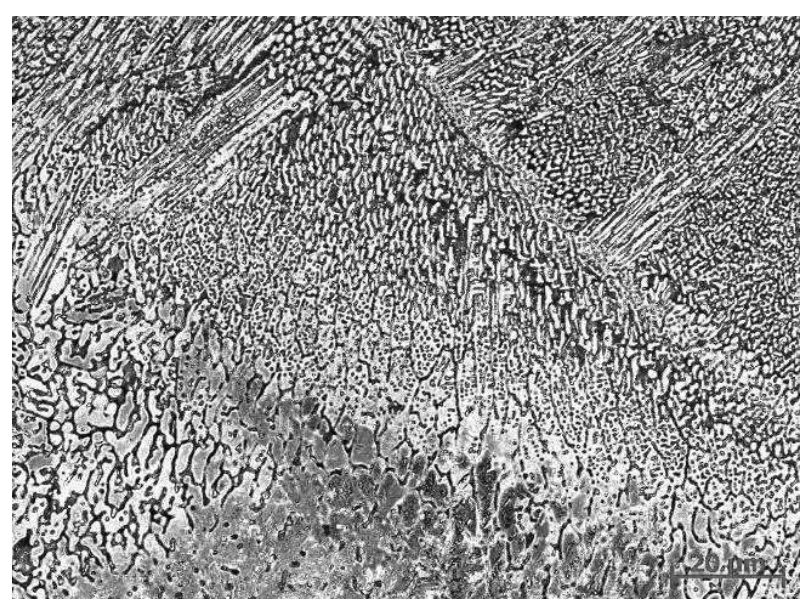

Fig. 4 ZONE 3; fusion boundary between the laser cladding and the substrate; etched with Robin, Nital $3 \%$; magnification $500 \times$

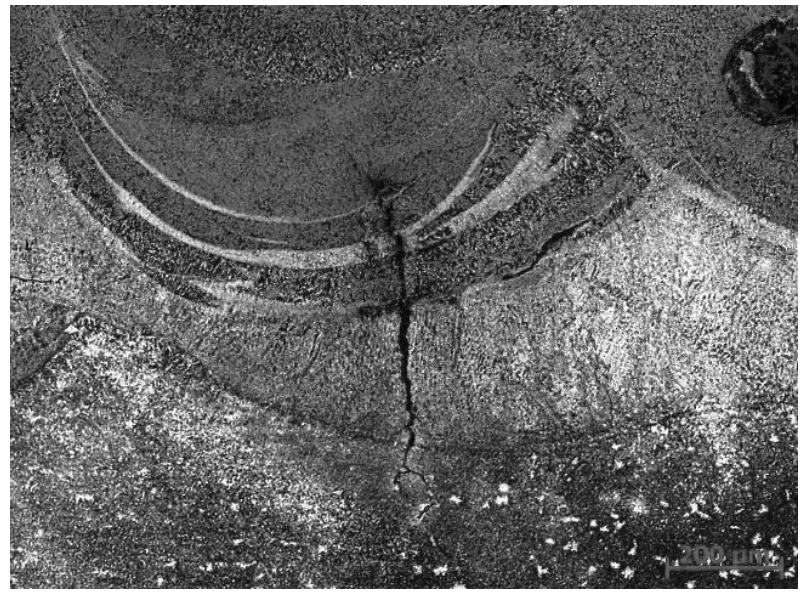

Fig. 5 ZONE 2; A crack running from layer B through layer $A$ to the substrate; etched with Robin, Nital 3\%; magnification $100 \times$

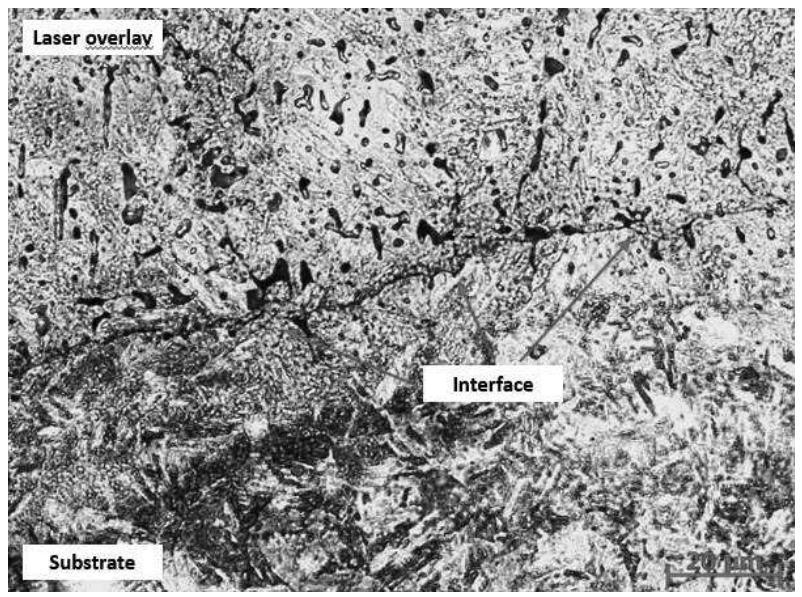

Fig. 6ZONE 5; fusion boundary between the laser cladding (layer A) and the substrate; etched with Robin, Nital $3 \%$; magnification $500 \times$
Fig. 7 and 8 show scanning electron micrographs of a transition region between layers of the composite copper-basalt laser cladding. Specifically, it is the transition region between layers $\mathrm{B}$ and $\mathrm{C}$. The microstructure of the composite consists of planar and cellular dendrites. Fig. 7 shows an interdendritic space (EDX-M1), whose chemical composition was measured using EDS (see Table 4). Fig. 8 is a micrograph of a basalt particle (EDX-M2) at the boundary between layers $\mathrm{B}$ and $\mathrm{C}$ of the cladding.

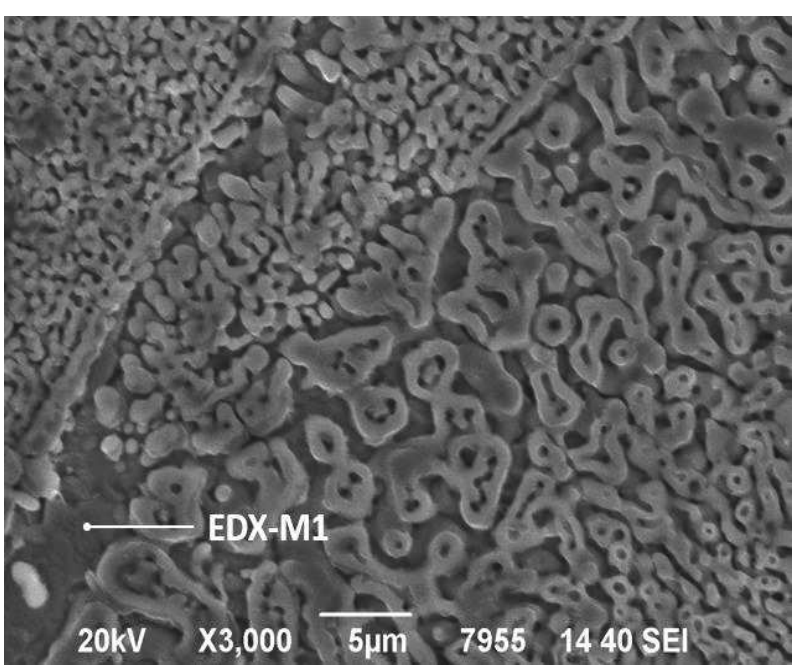

Fig. 7 Dendritic structure of the copper-basalt composite; transition between layers $B$ and $C$; the interdendritic space EDX-M1 is indicated; scanning electron micrograph; magnification $3000 \times[14]$

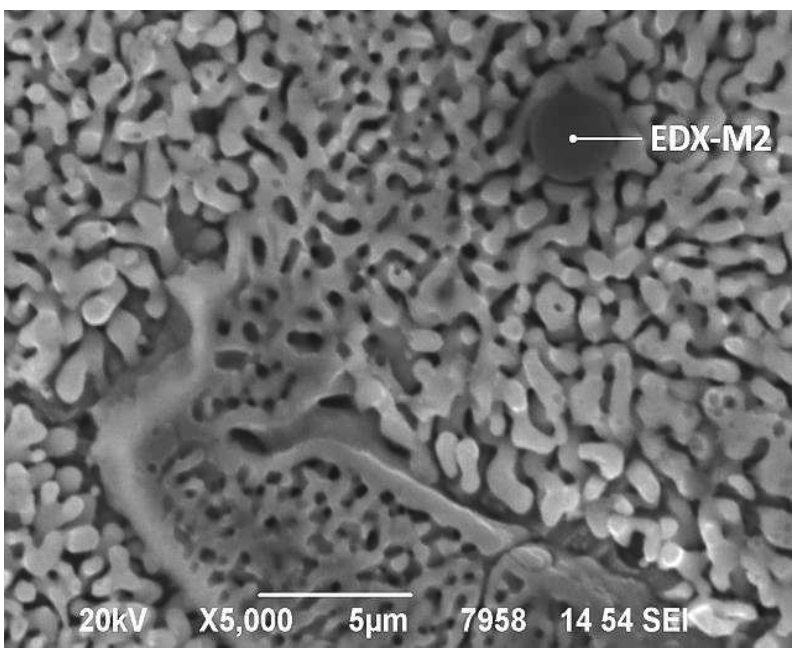

Fig. $\boldsymbol{8}$ Dendritic structure of the copper-basalt composite; transition between layers $B$ and $C$; the interdendritic space EDX-M2 is indicated; etched with the Robin reagent; scanning electron micrograph; magnification $5000 \times[14]$

Tab. 4 Inorganic powder substances, EDX analysis of chemical composition, element content in weight \% [14]

\begin{tabular}{lllllllllll}
\hline & $\mathbf{F e}$ & $\mathbf{C u}$ & $\mathbf{S i}$ & $\mathbf{M n}$ & $\mathbf{T i}$ & $\mathbf{C r}$ & $\mathbf{C 1}$ & $\mathbf{A l}$ & $\mathbf{M g}$ & $\mathbf{O}$ \\
\hline EDX - M1 & 8.5 & 89.6 & - & - & - & - & - & 1.9 & - & - \\
$\mathbf{E D X}-\mathbf{M} 2$ & 31.4 & 6.4 & 17.1 & 15.1 & 2.4 & 0.8 & 0.5 & 4.2 & 0.6 & 21.5 \\
\hline
\end{tabular}




\section{Mercedes Test of Adhesion of the Laser Cladding to Substrate}

The overall quality of the adhesive bond is influenced by many factors. To the most significant ones belong: the material of adhesive components, the surface treatment of adhesive areas and the quality of degreasing of adhesive areas. Another, but no less important, factors are the type of adhesive, the thickness of adhesive layer and the technology of adhesion [16].

The adhesion of the copper-basalt composite laser cladding to the $\mathrm{C} 45$ steel substrate was evaluated using the non-standardized Mercedes test. The surface of a laser cladding specimen was lightly ground to remove surface irregularities and then polished using the ordinary metallographic procedure. A total of three Rockwell impressions were made in the polished surface using a load of $1500 \mathrm{~N}$ and photographed using Nikon SMZ low-power stereomicroscope. Fig. 9 shows the impressions in the laser cladding surface. Red arrows in Fig. 9 indicate the propagation of surface cracks in the regions adjacent to the impressions. Adhesion was rated by comparing the cracks around the impressions with reference images (Fig. 10). Rockwell hardness (HRC) values and adhesion rating are summarized in Tab. 5.
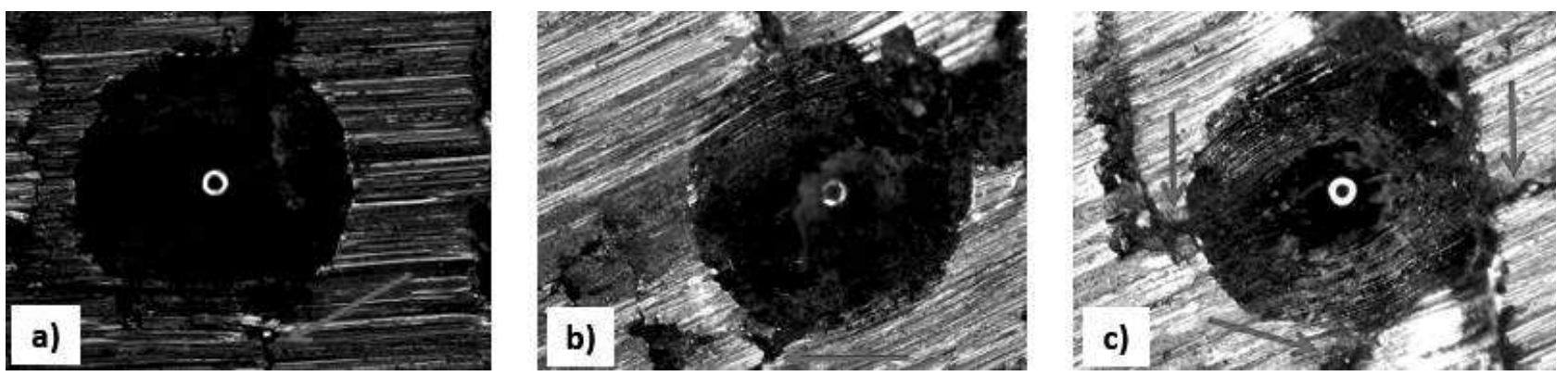

Fig. 9 Copper-basalt composite laser cladding; Rockwell impressions; a) impression 1; b) impression 2; c) impression 3

Tab. 5 Copper-basalt composite laser cladding; Rockwell hardness values and adhesion ratings

\begin{tabular}{ccccc}
\hline Specimen & \multicolumn{3}{c}{ HRC } & $\begin{array}{c}\text { Mercedes test for adhe- } \\
\text { sion evaluation }\end{array}$ \\
\cline { 2 - 4 } & Indent 1 & Indent 2 & Indent 3 & A2 \\
\hline $\begin{array}{c}\text { Composite laser clad } \\
85 \% \mathrm{Cu}+15 \% \text { basalt }\end{array}$ & 65 & 52 & 55 & \\
\hline
\end{tabular}

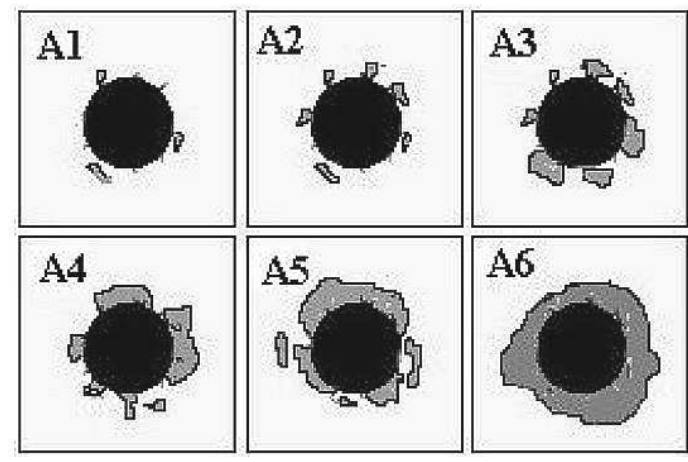

Fig. 10-Mercedes test - reference images for adhesive (A1 - A6) failure of coatings [17]

Adhesion was reduced by cracks which initiated in the laser cladding and spread all the way to the substrate (see Fig. 5).

\section{Potenciodynamic Corrosion Test}

Corrosion resistance of the composite laser overlays was assessed using potentiodynamic corrosion testing with the aid of BioLogic SP-150 potentiostat. EcLab 10.44 software was employed for data processing and evaluation. First, the time dependence was measured of the steady-state corrosion potential between WE - WORKING ELECTRODE and RE REFERENCE ELECTRODE. The time for stabilization of free corrosion potential was identical in all measurements $t_{R}=30 \mathrm{~min}$. Linear polarization was used for finding the dependence of corrosion current (converted to current density) on the mixed corrosion potential of the sample within the range from $E_{i}$ to $E_{L}$ $\left(\mathrm{E}_{\mathrm{i}}=\mathrm{E}_{\text {corr }}-0.025[\mathrm{~V}] ; \mathrm{E}_{\mathrm{i}}=\mathrm{E}_{\text {corr }}+0.025[\mathrm{~V}]\right)$ with respect to the reference electrode (RE). The Tafel lines obtained were extrapolated using software EcLab 10.44 and the polarisation resistance $R_{p}[m V]$ and corrosion rate $v_{\text {corr }}[\mu \mathrm{m} /$ year] were determined [3]. The reference electrode ("RE") was a calomel electrode and the counterelectrode ("CE") was a $0.3 \mathrm{~mm}$ diameter platinum wire, which supplied electric current to the corrosion cell to induce voltage changes between the specimen and the calomel electrode [3]. The electrolyte was a pH 3.5 artificial mine water. Its chemical composition and method of preparation are described in [18]. The $\mathrm{pH}$ value was determined using a litmus paper.

The corrosion resistance of the copper-basalt composite laser cladding was measured using the potentiodynamic corrosion test in five locations (ZONE 1 through ZONE 5) which are indicated in Fig. 1. As the laser cladding is heterogeneous in terms of 
microstructure, two measurements were performed in each region (ZONE 1 through ZONE 5). The purpose of this test was to determine corrosion rates in the individual regions. The data was converted to (linear) corrosion rates (corrosion losses) over 100000year period.

High-purity copper sheet and AISI 304 steel were used as reference standards in the potentiodynamic corrosion test.

Results of the potentiodynamic corrosion test of the copper-basalt laser cladding and the reference standards which included high-purity copper sheet and AISI 304 steel are summarized in Table 6.

Tab. 6 Potentiodynamic corrosion test; measured and calculated steady-state corrosion potential, polarisation resistance and corrosion rate

\begin{tabular}{|c|c|c|c|c|c|c|}
\hline $\begin{array}{l}\text { Designation of } \\
\text { sample }\end{array}$ & $\begin{array}{l}\text { Number of } \\
\text { measurements }\end{array}$ & $\begin{array}{l}\text { Corrosion po- } \\
\text { tential } \mathbf{E}_{\text {corr }} \\
{[\mathrm{mV} \text { vs } \mathrm{RE}]}\end{array}$ & $\begin{array}{l}\text { Polarisation } \\
\text { resistance } R_{p} \\
{[\Omega]}\end{array}$ & $\begin{array}{l}\text { Polarisation } \\
\text { resistance.S } \\
{\left[\Omega . \mathrm{cm}^{2}\right]}\end{array}$ & $\begin{array}{l}\text { Corrosion } \\
\text { rate } \\
{[\mu \mathrm{m} / \text { year }]}\end{array}$ & $\begin{array}{l}\text { Corrosion } \\
\text { rate over } \\
100000 \text { years } \\
{[\mathrm{mm}]}\end{array}$ \\
\hline \multirow{2}{*}{$\begin{array}{l}\text { Laser overlay } \\
\text { ZONE } 1\end{array}$} & 1 & -502 & 9862000 & 16537800 & 0.005 & 0.5 \\
\hline & 2 & -490 & 83405 & 153792 & 0.147 & 14.7 \\
\hline \multirow{2}{*}{$\begin{array}{l}\text { Laser overlay } \\
\text { ZONE } 2\end{array}$} & 3 & -520 & 8354000 & 14739200 & 0.008 & 0.8 \\
\hline & 4 & -508 & 135082 & 247300 & 0.233 & 23.3 \\
\hline \multirow{2}{*}{$\begin{array}{l}\text { Laser overlay } \\
\text { ZONE } 3\end{array}$} & 5 & -482 & 9355000 & 15237200 & 0.009 & 0.9 \\
\hline & 6 & -480 & 6534 & 12350 & 0.089 & 8.9 \\
\hline \multirow{2}{*}{$\begin{array}{l}\text { Laser overlay } \\
\text { ZONE } 4\end{array}$} & 7 & -525 & 7394600 & 11851000 & 0.622 & 62.2 \\
\hline & 8 & -510 & 10870000 & 17998800 & 0.003 & 0.3 \\
\hline \multirow{2}{*}{$\begin{array}{l}\text { Laser overlay } \\
\text { ZONE } 5\end{array}$} & 9 & -470 & 2302 & 4055 & 0.064 & 62.4 \\
\hline & 10 & -502 & 9625200 & 1685300 & 0.007 & 0.7 \\
\hline \multirow[t]{2}{*}{ AISI 304} & 1 & -162 & 52905 & 88952 & 0.988 & 98.8 \\
\hline & 2 & -168 & 40821 & 70204 & 1.235 & 123.5 \\
\hline \multirow[t]{2}{*}{$\mathrm{Cu}$ sheet } & 1 & -156 & 3513 & 7260 & 2.278 & 227.8 \\
\hline & 2 & -158 & 5490 & 11581 & 2.320 & 232.0 \\
\hline
\end{tabular}

The corrosion rates over a period of 100000 years calculated from the potentiodynamic corrosion test data indicate that the copper-basalt composite laser cladding is very heterogeneous in terms of both chemical composition and structure. ZONE 4 had the lowest corrosion rate $\mathrm{v}_{\text {corr }}=0.3 \mathrm{~mm} / 100000$ years, whereas ZONE 5 showed corrosion rate $v_{\text {corr }}=62.4 \mathrm{~mm} / 100000$ years. One of the causes of the considerable variation in corrosion rates of the copper-basalt composite found by the potentiodynamic corrosion test in artificial mine water was the presence of cracks in internal defects in the cladding.

\section{Conclusion}

The objective of this experimental work was to develop a new type of composite material with a highpurity copper matrix and basalt filler for laser deposition on steel substrates. Synergistic effects of the combination of components (copper and basalt) were exploited in this newly-developed composite to substan- tially improve its corrosion resistance in a specific environment. A 3-layer laser cladding was deposited using a powder which consisted of 85 wt. \% high-purity copper (Oerlicon METCO 55) and 15 wt. \% basalt powder. It was examined in five regions using metallographic techniques. It consisted predominantly of planar and cellular dendrites with distinct interdendritic spaces which contained mostly copper, as identified by EDS. Furthermore, cracks were found running from the laser cladding to the substrate. The adhesion of the claddings to the substrate was testing using the Mercedes test. The adhesion of the laser cladding to the substrate was rated A2 based on comparison of test results with reference standard images (Fig. 10). The corrosion resistance of the copper-basalt composite was measured using the potentiodynamic corrosion test in artificial mine water. The test was also performed on two reference materials: high-purity copper alloy C10100 and AISI 304 steel. The mean corrosion rate of the copper-basalt composite was $\mathrm{v}_{\text {corr }}=17.4 \mathrm{~mm} / 100000$ years. Although the corrosion 
resistance was severely reduced by cracks in the cladding, it was 5-13 times lower than in the reference specimens.

\section{Acknowledgement}

The above findings and results were achieved thanks to funding from the grant scheme of the University of West Bohemia-Motivation Scheme POSTDOC 2020.

\section{References}

[1] Správa úložišt' radioaktivních odpadů (Radioactive Waste Repository Authority). (2019). In Hlubinné úložistét. bttps://www.surao.č/wp-content/ uploads/2019/09/surao_brozuraHU_online.pdf [accessed on 30 June 2020]

[2] Správa úložišst' radioaktivních odpadů (Radioactive Waste Repository Authority). (2019). In Podzemni výzkumné pracovisté Bukov. bttps:/ / www.surao.cz/ wp-content/ uploads/2019/09/surao_brozura_bukov_online.pdf [accessed on 19 December 2020]

[3] KLUFOVA, P. (2018). Degradace laserem navařených austenitických vrstev. In: Dissertation thesis, University of West Bohemia

[4] HAJSMAN, J., JENICEK, S., KUCEROVA, L., RIEGER, D. (2019). Microstructure and properties of polymer composites. In: Manufacturing Technology, Vol. 19, No. 6, pp. 941 - 946. J. E. Purkyně University in Ústí nad Labem. Czech Republic. ISSN 1213-2489

[5] Oerlikon Metco. (2020). Datasheet - Metco 55, https://www.oerlikon.com [accessed on 28 June 2020]

[6] RONCHI, C., SHEINDLIN, M. (2001). Melting point of MgO. In: Journal of Applied Physics, Vol. 90, No. 7, pp. 3325 - 3331. American Institute of Physics. USA. ISSN 0021-8979

[7] KRACEK, F. C. (1963). Melting and transformation temperatures of mineral and allied substances. In: Geological Survey bulletin 1144-D. United states government printing office. Washington.

[8] Alfa Aesar. (2020). Datasheet - Calcium aluminium oxide, https://www.fishersci.co.uk [accessed on 28 June 2020]

[9] KUNO, H. (1966). Review of pyroxene relation in terrestrial rocks in the light of recent experimental works, In: Mineralogical journal, Vol. 5,
No. 1, p. 22 - 43. Japan Association of Mineralogical Sciences. Japan. ISSN 1881-4174

[10] MISRA, M. L. (1944). Sillimanit in India. In: Transactions of the Indian Ceramic Society, Volume 3, p. 65 - 69. Taylor \& Francis Ltd. UK. ISSN 0371-750X

[11] BOYD, F. R., ENGLAND, J. L., DAVIS, B. T. C. (1964). Effect of pressure on the melting temperature and polymorphism of enstatite, $\mathrm{MgSiO}_{3}$. In: Journal of Geophysical Research, Vol. 69, Issue 10, pp. 2101 - 2109. American Geophysical Union. USA. ISSN 0148-0227

[12] SCHNEIDER, H., FISCHER, R. X., SCHREUER, J. (2015). Mullite: Crystal structure and Related properties, In: Journal of the American Ceramics Society, Vol. 98, No. 10, pp. 2948 - 2967. The American Ceramics Society. USA. ISSN 1551-2916

[13] Přehled vlastností oceli C45, https://www.bolzano.cz [accessed on 27 July 2020]

[14] DULISKOVIC, J. (2020). Testování korozní odolnosti laserových návarů na bázi měd'-čedič ve specifických korozních prostředích. In: Diploma thesis. University of West Bohemia

[15] BARTON KLUFOVA, P., KRIZ, A., VOSTRAK, M. (2019). Development of Laser Clads with High Corrosion Resistance for Nuclear Power Industry. In: AIP Conference Proceedings, Vol. 2189, No. 1, pp. 020011-1 020011-8. American Institute of Physics Inc. USA. ISSN 0094-243X

[16] KALINA, T., SEDLACEK, F. (2019). Design and determination of strenght of adhesive bonded joints. In: Manufacturing Technology, Vol. 19, No. 3, pp. 409 - 413. J. E. Purkyně University in Ustí nad Labem. Czech Republic. ISSN 1213-2489

[17] SOSNOVA, M. (2007). Souvislost metod hodnocení adhezivně-kohezivního chování systému tenká vrstva-substrát. In: dissertation thesis, University of West Bohemia

[18] TITTEL, J. (2019). Testování korozní odolnosti kompozitních laserem navařených materiálů s vysokým poločasem rozpadu. In: diploma thesis, University of West Bohemia 